【論文】

\title{
微速モ一ドに基づく電動カートの操作支援に関する研究 Research on Driving Assistance of Electric Cart Using Low-Speed Mode
}

\author{
柴田論 (正会員) ，山本智規 (非会員) \\ 1. Satoru Shibata and 2. Tomonori Yamamoto
}

\begin{abstract}
Accidents of electric carts by the elderly persons increase rapidly. One of the reasons of them is lack of recognition of risks in surrounding circumstance. To prevent such accidents, an automatic support system of driving electric carts is considered. In the proposed system, when a step or a gap in front of an electric cart is detected by a laser range finder installed to the cart, a method named "low speed mode", which changes the region between maximum speed and minimum speed into lower speed level, is introduced. Time margin for the operation to avoid upcoming risks can be expected using "low speed mode". Impressions of drivers to the speed change when shifting from normal speed mode to low speed mode are examined by the psychological evaluations. Furthermore, experiments are conducted to examine whether the speed change can play the role to warn the upcoming risks to the driver.
\end{abstract}

\section{Key Words}

Driving Assistance of Electric Cart, Low Speed Mode, LRF Sensor, Human Emotions

\section{1. 緒言}

近年, 高齢社会の急速な進行に伴い, 下肢機能の衰えを 有する高齢者の自立支援のために, 電動カートの使用が増 加している. また, 下肢等に障がいを有する人々の移動手段 として電動カートが普及している. 一方で, 高齢者等の電動 カートでの事故も増加している ${ }^{1)}$.これは, 高齢者等の状況判 断能力, および反射的な運動能力の低下, 久如に起因して いる ${ }^{2}$. これらの能力の低下, 久如により, 実際の生活空間に おいて数多く存在する段差や溝などの, 見落としやすい危険 に対する認識遅れ, 落下回避操作等には様々な不安が伴う. これらの場面において, 操作性の改善や乗り心地, 操作支援 技術の導入が期待されている.

\section{0 年 3 月 16 日受理 \\ 2010 年 5 月 31 日最終原稿受理}

愛媛大学大学院理工学研究科, $\bar{\top} 790-8577$ 愛媛県松山 市文京町 3 番

Graduate School of Science and Engineering, Ehime University, 3, Bunkyo-cho, Matsuyama-shi, Ehime Prefecture, 790-8577, Japan
このような背景のもと, 電動車いすに関する研究もいくつか 行われている. 百生ら ${ }^{3}$ は, 乗り心地を考慮した電動車い寸 の制御を目指し，搭乗者を含めた電動車いすを一つの制御 系ととらえ, 制動時の上体の振れを抑制するために最適レギ ユレータによる安定化制御を行い, その効果を検証している. 小宮ら ${ }^{4)}$ は音声指令のみにより駆動する電動車い寸システム を構築し, 狭い空間による走行テストを通じてその有効性を 検討している.

これらの研究は, 主に乗り心地や操作性の改善に焦点が 当てられたものであり, 判断能力, 反射神経共に健常者に比 べて劣る可能性が高い搭乗者にとって, 早期の危険の認識 および回避のための操縦を必要とする場面における操作支 援技術に関する研究は重要である. そこで, 電動カートが前 方にある道路の段差や溝, 崖などに落下寸る事故を防止す るために, 電動カートの前方の段差を検出し, 搭乗者の操作 に対して適切なアシストを加える手法に注目した.この手法に 属する研究として, 鈴木ら ${ }^{5)}$ はミラー付きレーザレンジファイン ダを用いた電動車い寸運転時の下り段差の検知および回避 実験について検討している.ただし,この報告では検出距離 が $2 \mathrm{~m}$ 程度と短く, 電動車椅子の走行速度によっては回避運 
動が急激なものとなってしまう可能性が高い. また, 回避挙動 が人間心理に及ぼす影響については検討されていない.

本報告では, 計測距離性能の高いレーザレンジファインダ を用い, 遠距離にある段差障害物の計測方法を提案した. そ して段差検知後のアシスト手法として「微速モード」といら概念 を導入し, 通常速度から低速度域一速度を移行することによ る操縦支援の手法を提案した. すなわち, 搭乗者が段差に 対して接近している場合に, 電動カートに装着されたセンサ により段差の位置を認識し, 電動カートの速度範囲を自動的 に低速度域へと移行させる速度遷移を生じることによる操縦 の容易化を図った。これには，低速域一速度遷移させること で操作の余裕を操作者に与え, さらに, 速度の変化によって 操作者に危険を知らせるねらいがある. また，心理的に心地 よく, 操作者に安心感を与える速度遷移について検証し, 人 にやさしい操作支援システムの構築を目指した.

本研究では, まず, 微速モードへの移行のトリガーとなる, 電動カートに装着されたレーザレンジファインダを用いた周囲 環境に存在する複数の段差障害物の検出に関するアルゴリ ズムを構築した. 次に, 通常速度から低速度域一速度を移行 することによる操縦支援法である「微速モード」の概念を導入 した. そして, 実際の電動カートを用いた走行実験を行い, 被 験者に微速モードを実際に体験してもらつた際の効果につい て, 心理学的評価手法により検討した.

\section{2. センサによる段差検出}

本報告では, 周囲環境に存在する段差障害物を認識する ために用いるセンサとして, レーザレンジファインダ(以下， LRF)を用いた. LRF はレーザを用いた能動的なセンシング 方式であるため，その計測精度は高く，環境の明るさ，照明 に左右されないといら特徴を持つ.このことから, 移動ロボット の環境認識のためのセンサとして用いられている ${ }^{6), 7)}$.ここで は, そのような特徵を持つ LRF をもちいて, 電動カートが周囲 環境に存在する段差を計測・認識する一つの方法を示す.

\section{1 実験装置}

実験で使用する電動カートの実験機を Fig.1 に示す.この 電動カートは寸法 $1340 \times 700 \times 1100 \mathrm{~mm}$ で, 市版の電動カー 卜を参考にしており, 最大速度 $6 \mathrm{~km} / \mathrm{h}$ で走行する.

段差検出に用いるセンサとして，LRF（SICK 社製 LMS200-30106)を採用した. これは, 平面内走査型の距離セ ンサで, 検出範囲 $8000 \mathrm{~mm}$, サンプリングタイム $25 \mathrm{msec}$, 視野 $180^{\circ}$, 角度分解能 $1^{\circ}$ であり, サンプリングごとに検出範囲 の距離情報(すなわち, 180 個の距離データ)を取得する.な お最大計測誤差は土 $15 \mathrm{~mm}$ 未満である.ここでは, LRF を鉛 直方向に走査するように設置し, センサ本体が静止時には鉛 直平面内(以下, 走査平面内)の距離情報が取得できる. この LRF センサ本体を, ステッピングモータを用いて水平方向に 回転させることにより, 回転角度毎の鉛直平面内の距離情報, すなわち, 3 次元的な距離情報が取得できるようにした. 得ら れた距離情報を統合することにより, 周囲環境に存在する段
差障害物を推定することが可能となる.

まず，各回転角度位置における鉛直平面内での走行面と 段差障害物の境界であるエッジ候補点 (以下, エッジ候補 点)の抽出を, 全ての回転角度位置について行う. そして, 得 られた全ての段差障害物のエッジ候補点についてグループ 化を行い, 段差障害物の位置，大きさの推定を行うアルゴリ ズムを提案した.

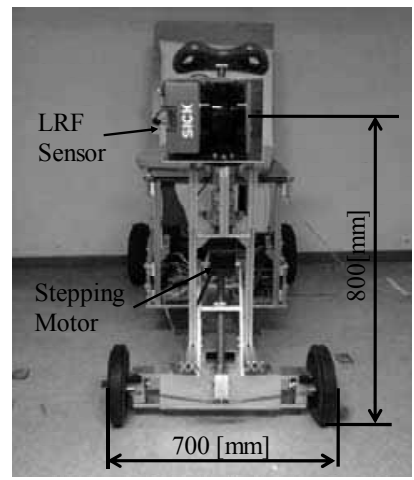

(a) Front view

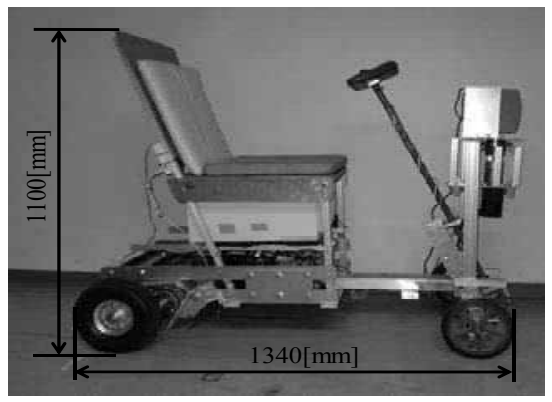

(b) Side view

Fig.1 Experimental electric cart with LRF sensor

LRF はステッピングモータ(ORIENTAL MOTOR 社製, AS66AE-N10)を用いて水平方向に回転し，電動カート真正 面を基準とする, 左右 $90^{\circ}$ に存在する段差障害物の検出を 試みる. 水平方向の回転分解能は $1.8^{\circ}$ である. これらの装 置を電動カートに取り付け, 電動カート走行中, 鉛直方向の 角度 $i$, 水平方向の角度 $j$ における LRF からの距離情報 $L_{i j}$ を測定した。

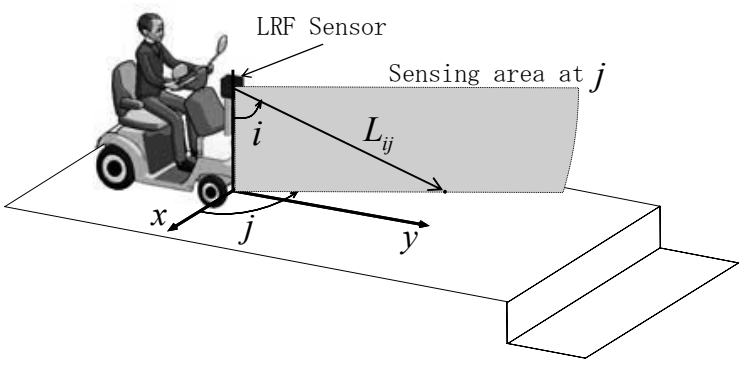

Fig.2 Sensing area and definition of angles 
Fig.2 そそれらの関係を示す.ここで， $i$ は鉛直方向の角 度位置に関する番号 $(i=0,1 \cdots 90)$ であり, LRF の回転中心 直下を $i=0$, 電動カート前方を $i=90$ とする. また, $j$ は水平方 向での回転角度に対応した番号 $(j=0, \cdots 100)$ であり, 電動 カート真正面に対して右側垂直方向を $j=0$, 電動カート真正 面を $j=50$ とする.

\section{2 エッジ候補点の抽出}

ある水平方向の回転位置 $j$ での走查平面の図を Fig.3 に 示す. LRF から得られる検出距離 $L_{i j}$ と検出角度 $i$ を基に段 差の存在を明らかにし, エッジ候補点を抽出する.

まず，あらかじめ走行面が平面である場合について $L_{i j}$ を測 定しておき,このときの $L_{i j}$ の值を平面のデータの理論值 $L_{R i j}$ とする.この $L_{R i j}$ を実際の走行時に計測した值 $L_{i j}$ と比較し, 段差の有無の判別を行う.ここでは, 落下の危険がある段差 について考える. このとき, $L_{i j}>L_{R i j}$ ならば段差であり, かつ, $L_{i-1 j}=L_{R i-1 j}$ ならば, $L_{i-1 j}$ と $L_{i j}$ の間に段差のエッジが存在す る.このとき, $L_{i-1 j}$ を段差のエッジの位置, 以下エッジ候補点 とする. エッジ候補点を $L_{i-1}$ としたのは, 安全性を考慮し, 電 動カートにより近い位置としたためである. また，ある水平方 向の回転位置において, 複数の候補点が存在する場合, 走 行における危険性が高いと思われる $i$ が最も小さい $L_{i-1 j}$ をエ ッジ候補点とする.

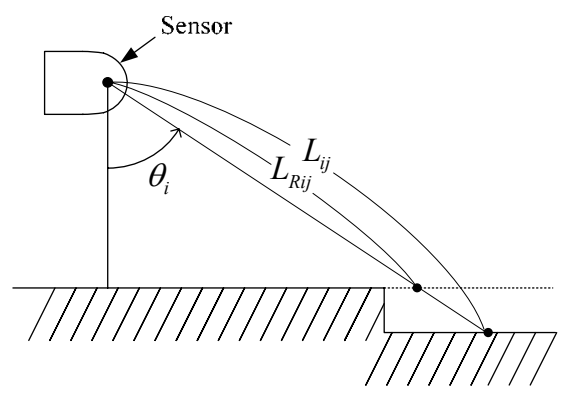

Fig.3 Comparison of the measured distance with the theoretical distance on the floor to detect gaps

次に, エッジ候補点のグループ化の判別のために抽出さ れたエッジ候補点の $x-y$ 座標系への変換を行う.ただし, 電動カートの走行開始地点を原点とし, 電動カートの進行方 向を $y$ 軸, 進行方向に対して垂直方向を $x$ 軸としている. ま た, 座標変換において, 電動カートの進行速度を $v$, 電動力 一ト走行開始から経過した時刻を $T$ とする. 変換された絶対 座標上のエッジ候補点を $\left(x_{i j}, y_{i j}\right)$ とすると, 絶対座標系への 変換式は, 式 (1)のように表される.

$$
\left(x_{i j}, y_{i j}\right)=\left(L_{i j} \sin \theta_{i} \cos \theta_{j}, L_{i j} \sin \theta_{i} \sin \theta_{j}+v T\right)
$$

\section{3 エッジ候補点列のグループ化}

得られたエッジ候補点から段差障害物の形状, 距離, 及 び方角を得るため, エッジ候補点をグループ化する. Fig.4 に 検出距離 $L_{i j}$ と水平方向の回転角度 $j$ の関係を表した上面
図を示す。

グループ化は，隣り合うエッジ候補点間の距離 (以下, 候 補点間距離)を基準に行うため, エッジ候補点水平方向の回 転角度番号である $j$ を0 から順番に比較する.もし Fig.4 のよ うに， $L_{i j-2}$ にエッジ候補点がなく， $L_{i j-1}$ にエッジ候補点があれ ば， $L_{i j-1}$ を要素とする段差障害物 $G_{0}$ をリストに新たに登録す る. $G_{k}$ は段差のグループであり， $k$ はグループ番号 $(k=0,1 \cdots)$ を表す. $L_{i j-1}$ と $L_{i j}$ の両方にエッジ候補点がある場 合に候補点間の距離を求め, あるしきい值より小さいとき，す なわち $\left|L_{i j}-L_{i j-1}\right|<T h r$ あるいは $\sqrt{\left(x_{i j}-x_{i j-1}\right)^{2}+\left(y_{i j}-y_{i j-1}\right)^{2}}<$ $T h r$ ならば $L_{i j-1}$ と $L_{i j}$ は同一の段差のエッジを表していると考 え, 段差障害物要素 $G_{0}$ に $L_{i j}$ を加える.ただし, Thr は䦭值 である. また $L_{i j+1}$ についても同様に, $\left|L_{i j+1}-L_{i j}\right|<T h r$ あるい は $\sqrt{\left(x_{i j+1}-x_{i j}\right)^{2}+\left(y_{i j+1}-y_{i j}\right)^{2}}<T h r$ ならば段差障害物の要 素に $L_{i j+1}$ を加える.ここで, $L_{i j+2}$ にエッジ候補点がなければ, 段差障害物の要素を確定し, もし， $L_{i j+2}$ がエッジ候補点であ っても， $L_{i j+1}$ と $L_{i j+2}$ の候補点間距離が $T h r$ より大きい場合， 段差障害物の要素を確定する. また, 段差障害物 $G_{k}$ の要素 が決定後, グループ番号 $k$ を更新する. 得られた段差障害 物のエッジの形状を推定するためには, グループ内の要素を 直線や曲線で近似することが考えられる.

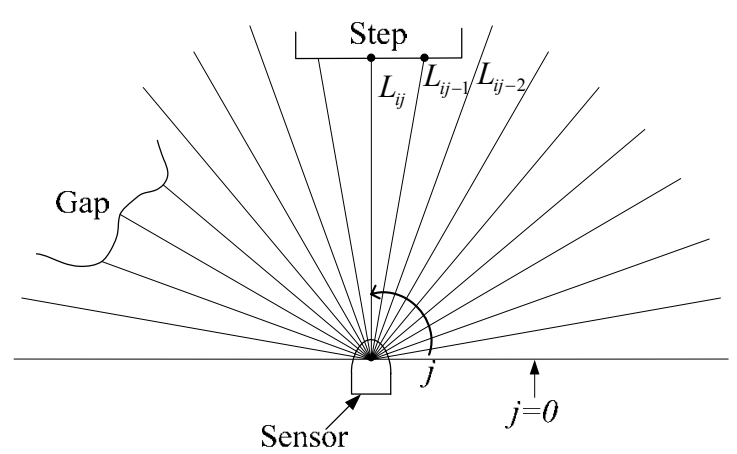

Fig. 4 Rotation of the sensor and detection of difference

\section{4 段差障害物検出実験}

提案した段差障害物検出アルゴリズムの有効性を確認す るための検証実験を行った.

\section{(1) 実験方法}

Fig.5 に実験環境を示す. 電動カートには LRF が取り付け られている. また, 電動カートは直進するが, その進行方向の 先には段差障害物を設けている. なお, 段差障害物は, 走行 面から $42 \mathrm{~cm}$ 下がっている.

ここでは, その段差障害物のエッジ部分の検出を提案した アルゴリズムに基づき行った。このとき，電動カートの走行開 始地点から段差までの距離を $15 \mathrm{~m}$ とし, 段差障害物の幅 $17.4 \mathrm{~m}, \mathrm{LRF}$ の取り付け高さ $0.85 \mathrm{~m}$ である. $E_{n}$ は段差障害物 
の推定を行ったときの原点からの距離を表す、実験における パラメータは, 電動カートの走行速度を $V_{\text {normal }}=4 \mathrm{~km} / \mathrm{h}$, $E_{n}=11 \mathrm{~m}$ とした. また, $T h r=1.5 \mathrm{~m}$ としている.

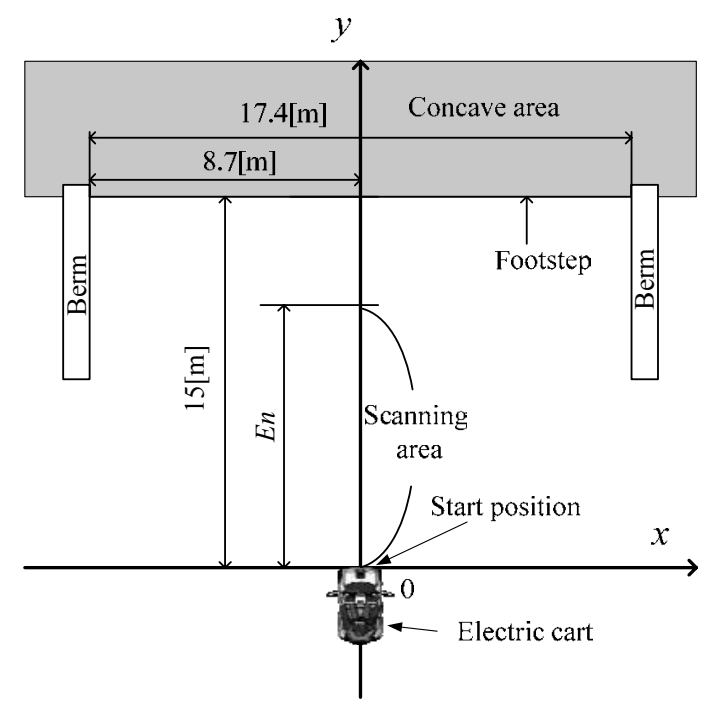

Fig.5 Experimental environment

\section{（2）実験結果および考察}

実験結果として, Fig.6 に $j=100$ における全ての検出点を 示す.ただし検出点は(1) 式を用いて, 絶対座標系に変換し たものを示す. 次に提案したアルゴリズムにより得られたエッ ジ候補点を Fig.7 に示す.

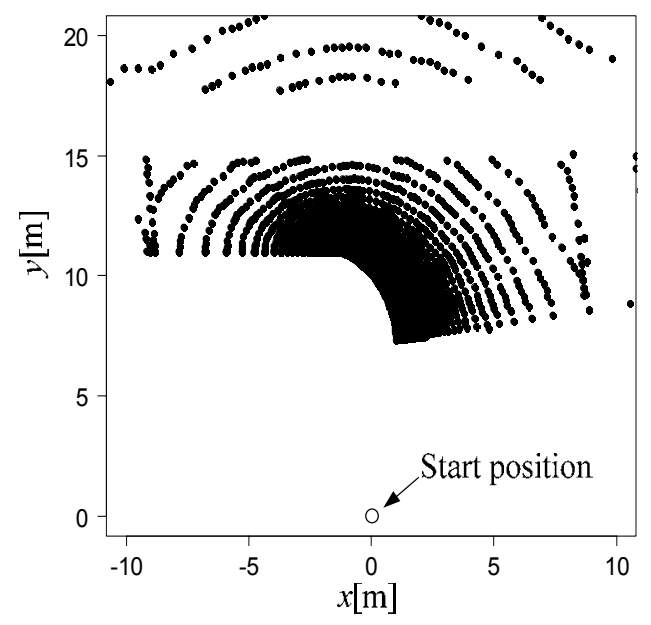

Fig. 6 All the detected points by the sensor

図を見て分かるように, 段差エッジは $G_{1}$ としてグループ化さ れており, 電動カートからの $y$ 軸方向の距離は $14.1 \sim 14.9 \mathrm{~m}$ の範囲内に分布している. この結果から分かるように, 段差障 害物の電動カートからの計測距離は, 実際の位置よりもやや 手前にあると認識されており, 安全面の観点からは望ましい 結果であると言える. また, 直線近似を行うことによって, 対象 の段差が直線状のエッジを有するものであることを予測する
のに役立つと考えられる.

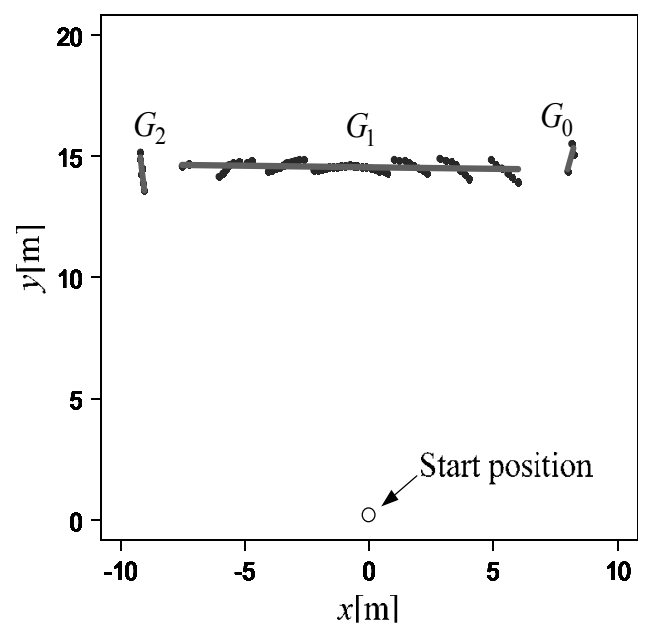

Fig.7 Recognized obstacles

ところで, 段差エッジ $G_{1}$ の $x$ 軸方向の分布は $-7.7 \sim 7.3 \mathrm{~m}$ となっており, 実際の幅 $17.4 \mathrm{~m}$ に比べてやや小さなものとなっ た.この誤差を軽減するためには, センサの水平方向の回転 分解能をさらにあげることが考えられるが，それは計測データ 量の増加に繋がり, 走行しながらの実時間処理を考えると難 しく, 今後の課題である.ただし, 次章で示す微速モードに基 づく走行支援は，進行方向前方の段差障害物の認識に基づ いているため, 電動カート前方の段差障害物を良好に計測・ 認識できている本実験結果は, 本センサシステムが微速モー ド活用のために有効であることを示しているといえる.

以上の実験結果は再現性のあるものであり, 5 回同様の実 験を繰り返しても電動カートからのエッジの $y$ 軸方向における 検出位置は $14.1 \sim 14.9 \mathrm{~m}$ の範囲内に分布し， $x$ 軸方向にお ける分布は-7.7〜 7.3m よりもその幅が小さくなることはなかっ た.

\section{3. 微速モ一ドの導入}

\section{1 微速モ一ドの概念}

操作支援システムである微速モードの概念を速度変化に より説明したものを Fig.8 に示す. 微速モードは, 電動カート の設定可能な通常の速度域の最小一最大の幅 $(2.0 \sim$ $6.0 \mathrm{~km} / \mathrm{h})$ を, センサによる障害物認知後に, ある変換係数を かけて得られる低速域 (以下, 微速) 一移行するものである. 本研究では, 基礎的な場合として, Fig.8の区間 BC で示され るように一定の加速度で減速する場合を考える.ここで, 通常 速度を $V_{\text {normal }}$, 微速を $V_{\text {low }}$ とする. Fig.8 より, まず, 電動車い すが通常速度で走行中，ある時点 A においてセンサが段差 障害物候補の信号を発生する. そして， $T_{r}$ の時間により前方 の段差障害物の存在を認識し, 段差障害物であることが確 認された後, 時点 B において微速モードへの速度変換を開 始する. そして, $T_{t}$ 時間後の時点 C において微速モードへの 
移行が終了する.この時, $\mathrm{BC}$ 閒における速度変化の傾き, つ

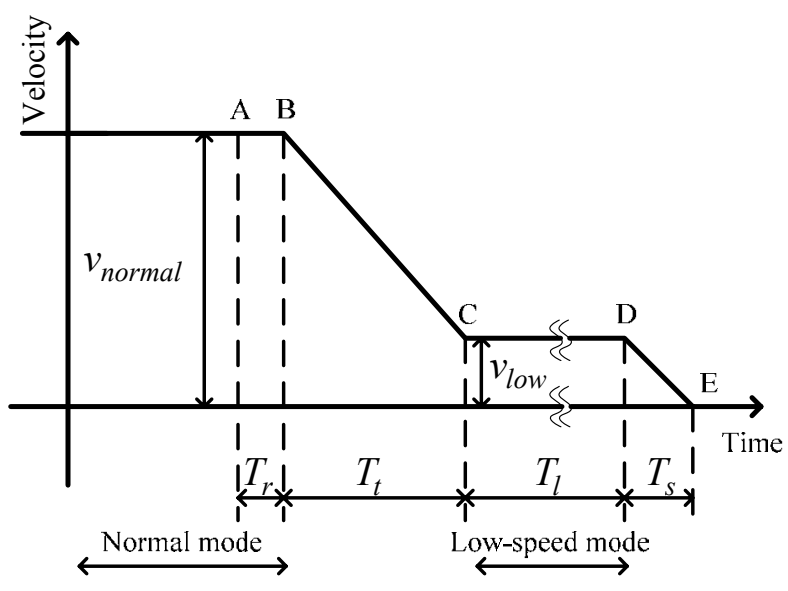

Fig.8 Velocity profile of transition from normal mode to low speed mode

まり加速度は負で一定である. その後, 微速を維持し, 走行 する. 微速モードへの移行の役割として, 速度を低下させるこ とによって段差の接近に対する操作に余裕を持たせる, 段差 への落下を回避するための時間的余裕を確保する, 速度変 化により搭乗者に段差の存在を知らせるといったものがある.

\section{2 微速モ一ドの有効性に関する検証実験}

\section{（1）実験方法}

ここでは搭乗者に微速モードを体感し評価してもらうため, Fig.8 の速度波形に従う走行を行う電動カートの搭乗実験を 行った. 電動カートに被験者が搭乗し, 前方 $10 \mathrm{~m}$ に存在する 段差に対して, 直進する. LRF センサが段差を検出すると, 電動カートは微速モードへの移行を開始する. 移行後は微 速を維持しつつ走行する. 段差への落下防止のため, 搭乗 者が落下防止のための操作を行わなかった場合は, 電動力 ートは段差障害物より手前で停止するように設定した. 実験 では, 通常時の速度を $4 \mathrm{~km} / \mathrm{h}$ とし, Table 1 に示されるような $T_{t}$ と $V_{\text {low }}$ のパラメータの組み合わせのもとに実験を行った. た だし, 表のように, 9 つの組み合わせそれぞれに対し, 1〜9の パラメータ番号を付した。

Table 1 Evaluated combinations of parameters

\begin{tabular}{|c|c|c|c|c|}
\hline & \multicolumn{3}{|c|}{$T_{t}[\mathrm{sec}]$} \\
\hline & & 1.5 & 1.0 & 0.7 \\
\hline \multirow{3}{*}{ 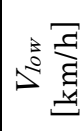 } & 0.5 & 1 & 2 & 3 \\
\hline & 1.0 & 4 & 5 & 6 \\
\hline & 1.5 & 7 & 8 & 9 \\
\hline
\end{tabular}

これらのパラメータの組み合わせを用いて微速モードへの 移行を行った際の被験者が受ける印象について明らかにす
るために, アンケート形式の心理評価を実施した. 心理評価 は, 評価すべき心理に関する複数の形容詞対を両極に配置 し，7段階のいずれかに被験者が○をつけるという評定尺度 法により行った. 形容詞対は電動車い寸が減速した場合, そ の速度変化が人間にとって安心できるものであり, 人閒心理 に好ましい反応をすべきであるという観点, および電動カート の操作において必要と思われる観点を考慮し，「安心できる 一不安な」,「感じの良い一不快な」,「滑らかな一ぎこちない」, 「落ち着いた一驚く」,「速い一遅い」,「やさしい一こわい」, 「好き一嫌い」の7個を選出した. また, 通常速度から微速モ 一ドに移行する際の速度変化が, 前方に段差障害物など危 険が迫っているということを搭乗者に伝える警告としての役割 を果たしているかどうか検証するために，上記の心理評価と 同様に，「警告になる一警告にならない」の 7 段階でアンケー 卜形式の評価を行ってもらった。実験は健常な成人男性・女 性 10 名 (22-25 歳)に対し行った. ただし, すべての被験者 に対して実験の目的および内容を説明し，十分なインフォー ムドコンセントが得られた後に実験を実施した. なお，実験に おける実施の順序はランダムに決定している. また, 学習の 転移を考慮し，1 つのパラメータ番号における実験を行った 後は少なくとも 1 週間は時間をおいて異なるパラメータ番号に ついて実験を行った。

\section{（2）実験結果および考察}

実験によって得られた心理評価結果から, 電動車いすの 動きに対し，人間がどのような印象を抱いたかについて検討 する. Fig.9 に心理評価結果の一例を示す.ただし, 図はパ ラメータ番号 1 , すなわち $T_{t}=1.5 \mathrm{sec}, V_{\text {low }}=0.5 \mathrm{~km} / \mathrm{h}$ の組み 合わせのときの心理評価結果である. ここで, 図は各段階に1 ずつの得点を与えたときの, 平均と標準偏差を示している.

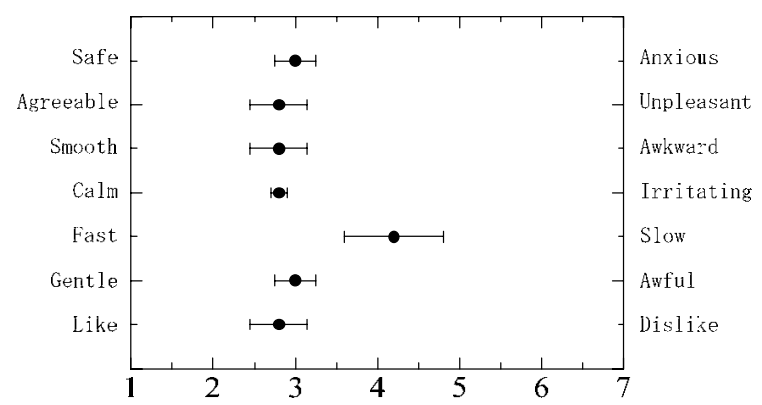

Fig.9 Results for the parameter number 1

図を見てわかるように, 速さに関する評価はほぼ中央の值 を示し, 速くも遅くもないという印象を示している. また, それ 以外の形容詞対については, 全て評価が中央より左寄り, す なわち優れているという印象を示している. この他, パラメータ 
番号 4,7 についても同様に被験者は優れた印象を抱いた. これらのパラメータについて共通することは, 負の加速度の絶 対值が比較的小さいことである.

これら以外のパラメータ番号については, いずれも好ましい 結果は得られなかった. その一例として, パラメータ番号 6 の 時の心理評価結果を Fig.10 に示す.

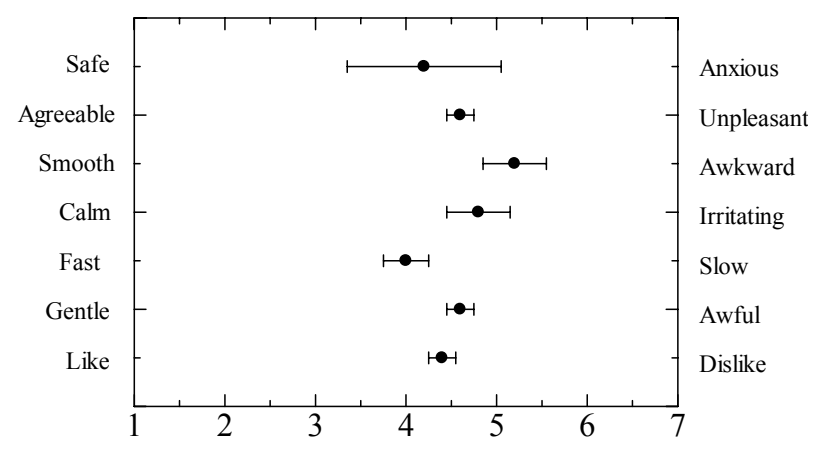

Fig.10 Results for the parameter number 6

図を見てわかるように, 速さに関する評価はほぼ中央の值 を示し, 速くも遅くもないという印象を示している. しかしながら, 安心感についてはばらつきが大きく, それ以外の形容詞対に ついては, 全て評価が中央より右寄り, 寸なわちネガティブな 印象を示した。

次に, 微速モードが搭乗者にとって段差障害物の接近を 知らせるための警告になりうるかについての検討を行う. Fig.11 は, 通常速度から微速一と移行する際の負の加速度 の大きさの観点から, 警告になりうるかについて示したもので ある.ただし, 図中の番号は, パラメータの組み合わせ番号を 示している.

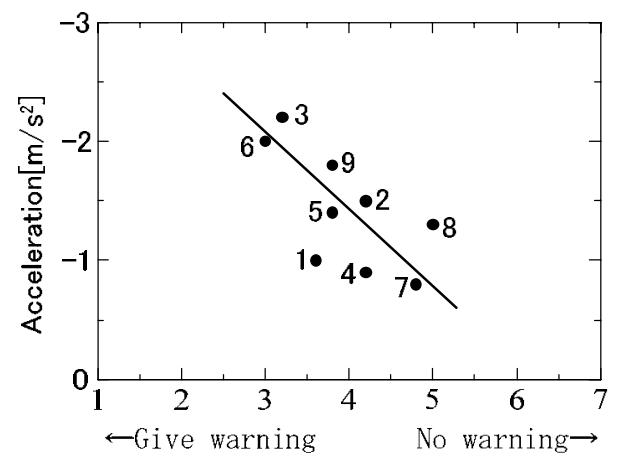

Fig.11 Relation between parameter numbers and ability of warning

図を見てわかるように, 負の加速度の絶対值が大きいほど 警告としての評価は高い傾向がある. ただし, パラメータ番号 1 のように, 警告としての評価が中央より左に位置しており, か つ心理評価結果が望ましいパラメータの組み合わせが存在 することは注目すべきことであると思われる.

\section{4. まとめ}

本報告では, 電動カートが前方にある道路の段差や溝, 崖 などに落下する事故を防止するために, 電動カートの前方の 段差を LRF センサにより検出し, 搭乗者の操作に対して適切 な速度調整を行う「微速モード」という支援方法を提案した。

まず, 微速モードへの移行の指標となる, 電動カートに装 着された LRF センサを用いた周囲環境に存在する複数の段 差障害物の検出に関するアルゴリズムを構築した. 次に, 通 常速度から低速度域へ速度を移行することによる操縦支援 法である「微速モード」の概念を提案した. そして, 実際の電 動カートを用いた走行実験を行い, 微速モードのパラメータ の組み合わせによっては, 心理的に好ましく, かつ搭乗者に 段差障害物の危険の接近を知らせる効果があることを明らか にした.

なお, 微速モード移行に関して, 減速時間の長さや最終速 度というパラメータがどのように人間心理に影響を与えるかは 重要であるため, 今後それらをパラメータとして実験を行い, 明らかにしていきたい.また，段差障害物の回避が終了した 際の, 微速モードから通常走行へ戻るプロセスについても今 後検討していく予定である.

\section{参考文献}

1)電動車いすの安全利用に関するマニュアル. 警察庁交通企 画課 2009.

2) 百生登, 大島徹, 池田都砂子, 乗り心地を考慮した電動車 いすの制御。日本機械学会論文集C編 2004; 70 (689)： 207-212.

3）小宮加容子, 中島康博, 橋場参生, 景川耕宇, 黒須亜顕 二狭い空間における音声指令による電動車いす走行テスト. 日本機械学会論文集C編 2003; 69 (688):3350-3357.

4）藤井文武, 和田憲造, 乗り手にやさしい電動車いすの実現 に関寸る研究.日本機械学会論文集 C編 2000;66(645)： 1645-1651.

5）鈴木雄介, 松本治, 足立吉隆, ミラー付きLRFを用いた電 動車いすの危険回避に関する研究〜下り段差検知・回避 実験〜. 第 27 回 日本ロボット学会 学術講演会講演予稿 集 $2009 ; 2 \mathrm{C} 2-03$.

6）竹内栄二朗, 坪内孝司, 移動ロボットによる環境地図生成 のための 3 次元化 NDT を用いた高速 3 次元スキャンマッチ ング.第 11 回 ロボティクスシンポジア予稿集 2006 : $252-257$.

7）橋本雅文, 緒方聡, 大場史憲, 岡田三郎, 車載レーザレン ジセンサによる複数移動物体の検出・追跡法, 日本機械学 会論文集C編 2006;72(717)：1566-1573. 